\title{
Fresh Semen Characteristics of Large white Yorkshire Boar Semen Selected for Liquid Semen Preservation
}

\author{
T. Shylesh ${ }^{1}$, Hiron M. Harshan ${ }^{1}$, Megha Wilson ${ }^{2}$, K. Promod ${ }^{1}$, \\ A. P. Usha ${ }^{3}$, C. Sunanda ${ }^{4}$ and M. P. Unnikrishnan ${ }^{4}$ \\ ${ }^{1}$ Department of Animal Reproduction, Gynaecology and Obstetrics, CVAS, Pookode, India \\ ${ }^{2}$ Poultry Division, Brahmagiri Development Society, Sultanbathery, India \\ ${ }^{3}$ Centre for Pig Production and Research, Mannuthy, India \\ ${ }^{4}$ Department of Statistics, CVAS, Pookode, India \\ *Corresponding author
}

\section{A B S T R A C T}

Keywords

Progressive Motility, Viability, Abnormality, Acrosome integrity, HOST

Article Info

Accepted:

18 August 2019

Available Online:

10 September 2019
The laboratory examination of semen quality parameters is an indirect way of assessing male fertility. The objective of this research was to study the semen quality parameters of Large White Yorkshire (LWY) boar ejaculates, which had the minimum sperm progressive motility necessary for being selected for further processing. The pigs were maintained at the Centre for pig production and research, Mannuthy, Kerala. A total of 24 ejaculates were collected from seven boars using gloved hand technique. The collected semen was examined for volume, colour, $\mathrm{pH}$, sperm concentration, progressive motility, viability, abnormality, acrosome integrity and functional membrane integrity. Gel free volume differed significantly between boars. There was no significant difference observed in $\mathrm{pH}$, sperm concentration and progressive motility among the seven boars studied. Significantly higher $(\mathrm{p}<0.05)$ viable sperms were observed in few boars. Similar observations were noted with respect to sperm abnormality too. Significant differences $(\mathrm{p}<0.05)$ were observed in acrosome integrity and hypo-osmotic sperm swelling response among boars.

\section{Introduction}

Pigs offer a great support to livestock farmers due to their high prolificacy, feed conversion efficiency, short generation interval and smaller capital investment. For ensuring revenue from the venture, the breeding efficiency from the pigs has to be ensured. Though artificial insemination (AI) in pig industry plays a major role in upgradation of species, it is not as popular as in cattle because of limitations of semen quantity required for 
insemination and poor preservability (especially freezability) of boar semen. The laboratory evaluation of semen quality parameters is a convenient indirect way of assessing male fertility, without conducting an artificial insemination trial on each ejaculate. Hence, the article describes the normal parameters of LWY boar semen reared under Kerala conditions.

\section{Materials and Methods}

Twenty four ejaculates from seven LWY boars aged between 12-24 months, maintained at the Centre for Pig Production and Research, Mannuthy, were collected using gloved hand technique and a dummy mount. The semen was collected into a pre-warmed amber coloured insulated conical flask after allowing it to pass through a Buchner funnel to separate the gel mass. The collected semen was immediately transported to the laboratory for preliminary evaluation in an insulated container. The fresh semen collected was evaluated for volume, colour, $\mathrm{pH}$, concentration, progressive motility, sperm viability, sperm abnormality, acrosome integrity and sperm response to hypo-osmotic swelling test (HOST). The volume of the semen ejaculate was measured by using graduated class A glass cylinder of $250 \mathrm{~mL}$ capacity. The colour of each ejaculate was visually assessed and $\mathrm{pH}$ was measured using hand held $\mathrm{pH}$ meter (Horiba, Model LAQUAtwin pH-11, USA). The sperm concentration in the semen was evaluated by haemocytometer method (Salisbury et al., 1985). Sperm progressive motility was recorded as a per cent of individual motility of the spermatozoa after diluting the semen. Only ejaculates with more than 70 per cent progressive motility were selected for further evaluation. Thus comparison was made between ejaculates found suitable for liquid semen preservation. Sperm viability and abnormality was assessed using eosin-nigrosin staining technique as described by Campbell et al., (1953) sperm acrosome integrity by Giemsa staining technique as described by Watson (1975) and the functional membrane integrity of the spermatozoa was assessed by HOST response as per the method described by Jeyendran et al., (1984).

Percentage data recorded were transformed using Arcsine prior to analysis. Treatment means were compared using one way Analysis of variance (ANOVA).

\section{Results and Discussion}

The colour of the gel free ejaculates ranged from milky to thick milky. Of the 24 ejaculates collected, two had thin milky colour, seventeen had milky colour and five had thick milky colour. The observations of the current study were similar to the findings of Sreekumaran (1974). Frunza et al., (2008) reviewed that the normal colour for boar semen ejaculate was white with bluish shadows. A decrease in spermatozoa concentration (even due to increased frequency of collections) made the semen colour to appear clear.

The volume of the semen ejaculates ranged between $120-280 \mathrm{~mL}$, with a mean volume of $197.33 \pm 8.65 \mathrm{~mL}$. The volume of semen was significantly higher $(\mathrm{p}<0.01)$ in boar 1 and 3 ; and significantly lower $(\mathrm{p}<0.01)$ in boar 5 . The observed gel free ejaculate volume was similar to those observed by Kantharaj (2001) in LWY (209.50 $\pm 4.63 \mathrm{~mL})$. Hafez (1993) recorded a range of $50-400 \mathrm{~mL}$ for semen volume in boars. The semen volume observed in the present study fell within these reported ranges.

The overall average fresh semen $\mathrm{pH}$ was found to be on the alkaline side $(7.39 \pm 0.03)$, ranging from 7.10-7.60. On an individual boar basis the $\mathrm{pH}$ was found to range from $7.30 \pm$ 
0.09 to $7.50 \pm 0.00$. There was no significant difference observed in the $\mathrm{pH}$ of semen ejaculates between the boars. According to Johnson et al., (2000), the $\mathrm{pH}$ of boar semen ejaculate was in the range of 7.2-7.5, which was in accordance to the findings in the current work. The $\mathrm{pH}$ recorded by Strzezek et al., (1995) in Yorkshire boar semen was slightly lower $(7.1 \pm 0.07)$. Semen ejaculates of the same animal can differ in its $\mathrm{pH}$. A higher contribution of accessory sex gland secretions to the ejaculate, increased the alkalinity of semen (Mann, 1974).

The overall sperm concentration ranged from 140 to 310.8 million $/ \mathrm{mL}$ with a mean $\pm \mathrm{SE}$ of $236.82 \pm 9.49$ million $/ \mathrm{mL}$. On an individual boar basis the sperm concentration varied from $166.67 \pm 13.33$ to $276.67 \pm 12.02$ million/mL. No significant variation was observed among the sperm concentration between the seven boars. This was in accordance with the observations of Labussiere (1990; 200-300 million/mL) and Strzezek et al., $(1995 ; 211 \pm 22.07$ million sperms $/ \mathrm{mL}$ ) in Yorkshire boar semen. Kantharaj (2001) recorded a sperm concentration of 261-329 million/mL with an average of $288.28 \pm 2.73 \mathrm{million} / \mathrm{mL}$ in LWY boar semen, which was slightly higher than the concentration observed in the present study. The sperm concentration in the semen decreases as the frequency increases. With increasing frequency, the ejaculate volume is mainly contributed by seminal fluid from accessory glands and there will be a reduction in the concentration.

The overall sperm progressive motility, immediately after collection, ranged from $75.00-85.00$ per cent with an average of $79.38 \pm 0.76$ per cent. Individual boar progressive motile sperm per cent varied from $75.00 \pm 0.00$ to $83.33 \pm 1.67$. No significant difference was observed in progressive motility of sperm in fresh semen between boars, which was in agreement with the findings of Kantharaj (2001). Much lower values of 65.70 per cent were observed by Sreekumaran (1974) with LWY boars. Cerolini et al., (2001) recorded motility of $63.00 \pm 2.20$ per cent in a study which included boars of different genetic lines (Landrace, Large White and commercial hybrids).

In current study, the mean \pm SE sperm viability in the fresh semen samples was found to be $84.00 \pm 0.83$ with the range of $77-90$ per cent. Individual boar viable sperm per cent varied from $79.00 \pm 0.91$ to $88.50 \pm 1.26$. Significantly higher $(\mathrm{p}<0.05)$ viability was found in boar 1 and significantly lower $(\mathrm{p}<0.05)$ viability was found in boar 5 . The recorded values were found to be much closer to values obtained in LWY boars by Murthy (1974, 84.5 per cent) and slightly higher values was reported by Sreekumaran (1974, 88.8 per cent) and Kantharaj (2001, $87.53 \pm$ 0.56 per cent). The sperm viability observed was also lower to those observed in Hampshire boars $(90.92 \pm 1.56$ per cent, Kumaresan et al., 2009) and LWY boars $(92.40 \pm 0.28$ per cent, Lalrintluanga et al., 2016). The observed differences could be due to variations in season and handling of semen.

The overall mean \pm SE sperm abnormality recorded in the present study of fresh ejaculate obtained from LWY boars was $6.15 \pm 0.57$ per cent with a range of $2.00-12.00$ per cent. On an individual boar basis the sperm abnormality varied from $3.17 \pm 0.44$ to $9.50 \pm 1.19$ per cent. Significantly higher $(\mathrm{p}<0.05)$ abnormality was found in boar 6 and significantly lower $(p<0.05)$ abnormality was found in boar 1 . These findings were in close agreement with the values reported by Kantharaj (2001) in LWY boars (6.88 \pm 0.40 , ranged from $1.67-10.67)$. 
Table.1 Fresh semen characteristics of Large white Yorkshire boars ( $n=24$; Range, Mean \pm SE)

\begin{tabular}{|c|c|c|c|c|c|}
\hline $\begin{array}{c}\text { Semen } \\
\text { characteristics }\end{array}$ & Animal & Range & Mean \pm SE & $\begin{array}{c}\text { Overall Mean } \\
\pm \text { SE and } \\
\text { range } \\
(n=24)\end{array}$ & $\begin{array}{c}\text { F-value } \\
\text { (p-value) }\end{array}$ \\
\hline \multirow{7}{*}{$\begin{array}{c}\text { Gel free } \\
\text { volume }(\mathrm{mL})\end{array}$} & Boar $1(n=3)$ & $226-280$ & $238.67 \pm 21.18^{\mathrm{a}}$ & \multirow{7}{*}{$\begin{array}{c}197.33 \pm 8.65 \\
120.00- \\
280.00\end{array}$} & \multirow{7}{*}{$\begin{array}{l}4.802 * * \\
(0.005)\end{array}$} \\
\hline & Boar $2(n=3)$ & $165-243$ & $208.00 \pm 22.87^{\mathrm{abc}}$ & & \\
\hline & Boar $3(n=3)$ & $220-270$ & $248.67 \pm 14.89^{\mathrm{a}}$ & & \\
\hline & Boar $4(n=3)$ & $209-225$ & $216.67 \pm 4.63^{\mathrm{ab}}$ & & \\
\hline & Boar $5(n=4)$ & $140-200$ & $162.50 \pm 13.15^{\mathrm{c}}$ & & \\
\hline & Boar $6(n=4)$ & $120-210$ & $165.00 \pm 19.36^{\mathrm{bc}}$ & & \\
\hline & Boar $7(n=4)$ & $150-200$ & $172.50 \pm 11.09^{b c}$ & & \\
\hline \multirow[t]{7}{*}{ pH } & Boar $1(n=3)$ & 7.4-7.5 & $7.43 \pm 0.03$ & \multirow{7}{*}{$\begin{array}{l}7.39 \pm 0.03 \\
7.10-7.60\end{array}$} & \multirow{7}{*}{$\begin{array}{l}0.787^{\mathrm{ns}} \\
(0.592)\end{array}$} \\
\hline & Boar $2(n=3)$ & 7.3-7.5 & $7.43 \pm 0.07$ & & \\
\hline & Boar $3(n=3)$ & 7.3-7.6 & $7.43 \pm 0.09$ & & \\
\hline & Boar $4(n=3)$ & 7.5 & $7.5 \pm 0.00$ & & \\
\hline & Boar $5(n=4)$ & $7.1-7.5$ & $7.30 \pm 0.09$ & & \\
\hline & Boar $6(n=4)$ & 7.1-7.6 & $7.30 \pm 0.11$ & & \\
\hline & Boar $7(n=4)$ & 7.1-7.5 & $7.38 \pm 0.09$ & & \\
\hline \multirow{7}{*}{$\begin{array}{l}\text { Concentration } \\
(\text { millions/mL) }\end{array}$} & Boar $1(n=3)$ & $210-280$ & $240 \pm 20.82$ & \multirow{7}{*}{$\begin{array}{c}236.82 \pm 9.49 \\
140.00- \\
310.80\end{array}$} & \multirow{7}{*}{$\begin{array}{l}2.270^{\mathrm{ns}} \\
(0.086)\end{array}$} \\
\hline & Boar $2(n=3)$ & $260-300$ & $276.67 \pm 12.02$ & & \\
\hline & Boar $3(n=3)$ & $180-260$ & $226.67 \pm 24.04$ & & \\
\hline & Boar $4(n=3)$ & $140-180$ & $166.67 \pm 13.33$ & & \\
\hline & Boar $5(n=4)$ & $141.75-271.95$ & $234.46 \pm 31.11$ & & \\
\hline & Boar $6(n=4)$ & $220-310.8$ & $259.13 \pm 19.11$ & & \\
\hline & Boar $7(n=4)$ & $210-293$ & $244.83 \pm 17.38$ & & \\
\hline
\end{tabular}

**: Means with different superscript in a column for a given parameter differ significantly $(p<0.01),{ }^{n s}$ : nonsignificant 
Table.2 Progressive motility, viability, abnormality, acrosome integrity and functional membrane integrity in freshly ejaculated sperm of Large white Yorkshire boars $(n=24$; Range, Mean $\pm \mathrm{SE}$ )

\begin{tabular}{|c|c|c|c|c|c|}
\hline $\begin{array}{c}\text { Sperm } \\
\text { characteristics }\end{array}$ & Animal & Range & Mean \pm SE & $\begin{array}{c}\text { Overall Mean } \\
\pm S E \text { and } \\
\text { range }(n=24)\end{array}$ & $\begin{array}{l}\text { F-value } \\
\text { (p-value) }\end{array}$ \\
\hline \multirow{7}{*}{$\begin{array}{c}\text { Progressive } \\
\text { motility } \\
\text { (in per cent) }\end{array}$} & Boar $1(n=3)$ & $80.00-85.00$ & $81.67 \pm 1.67$ & \multirow{7}{*}{$\begin{array}{c}79.38 \pm 0.76 \\
75.00-85.00\end{array}$} & \multirow{7}{*}{$\begin{array}{l}1.884^{\mathrm{ns}} \\
(0.142)\end{array}$} \\
\hline & Boar $2(n=3)$ & $80.00-85.00$ & $83.33 \pm 1.67$ & & \\
\hline & Boar $3(n=3)$ & $75.00-85.00$ & $80.00 \pm 2.89$ & & \\
\hline & Boar $4(n=3)$ & 75.00 & $75.00 \pm 0.00$ & & \\
\hline & Boar $5(n=4)$ & $75.00-85.00$ & $78.75 \pm 2.39$ & & \\
\hline & Boar $6(n=4)$ & $75.00-80.00$ & $78.75 \pm 1.25$ & & \\
\hline & Boar $7(n=4)$ & $75.00-80.00$ & $78.75 \pm 1.25$ & & \\
\hline \multirow{7}{*}{$\begin{array}{l}\text { Sperm viability } \\
\text { (in per cent) }\end{array}$} & Boar $1(n=3)$ & $86.00-90.00$ & $88.50 \pm 1.26^{\mathrm{a}}$ & \multirow{7}{*}{$\begin{array}{c}84.00 \pm 0.83 \\
77.00-90.00\end{array}$} & \multirow{7}{*}{$\begin{array}{l}3.473 * \\
(0.020)\end{array}$} \\
\hline & Boar $2(n=3)$ & $83.50-90.00$ & $86.50 \pm 1.89^{\mathrm{ab}}$ & & \\
\hline & Boar $3(n=3)$ & $82.00-87.00$ & $85.17 \pm 1.59^{\mathrm{ab}}$ & & \\
\hline & Boar $4(n=3)$ & $83.00-89.00$ & $85.83 \pm 1.74^{\mathrm{ab}}$ & & \\
\hline & Boar $5(n=4)$ & $77.00-81.00$ & $79.00 \pm 0.91^{\mathrm{c}}$ & & \\
\hline & Boar $6(n=4)$ & $78.00-86.00$ & $82.25 \pm 1.93^{b c}$ & & \\
\hline & Boar $7(n=4)$ & $78.00-87.00$ & $83.25 \pm 2.06^{\mathrm{abc}}$ & & \\
\hline \multirow{7}{*}{$\begin{array}{c}\text { Sperm } \\
\text { abnormality } \\
\text { (in per cent) }\end{array}$} & Boar $1(n=3)$ & $2.50-4.00$ & $3.17 \pm 0.44^{\mathrm{c}}$ & \multirow{7}{*}{$\begin{array}{c}6.15 \pm 0.57 \\
2.00-12.00\end{array}$} & \multirow{7}{*}{$\begin{array}{l}3.001^{*} \\
(0.035)\end{array}$} \\
\hline & Boar $2(n=3)$ & $3.00-7.00$ & $5.33 \pm 1.20^{\mathrm{bc}}$ & & \\
\hline & Boar $3(n=3)$ & $7.00-9.00$ & $8.00 \pm 0.58^{\mathrm{ab}}$ & & \\
\hline & Boar $4(n=3)$ & $4.00-8.00$ & $6.00 \pm 1.15^{\mathrm{abc}}$ & & \\
\hline & Boar $5(n=4)$ & $2.00-10.00$ & $5.50 \pm 1.71^{b c}$ & & \\
\hline & Boar $6(n=4)$ & $7.00-12.00$ & $9.50 \pm 1.19^{\mathrm{a}}$ & & \\
\hline & Boar $7(n=4)$ & $2.00-7.00$ & $5.00 \pm 1.08^{\mathrm{bc}}$ & & \\
\hline \multirow{7}{*}{$\begin{array}{c}\text { Sperm } \\
\text { acrosomal } \\
\text { integrity } \\
\text { (in per cent) }\end{array}$} & Boar $1(n=3)$ & $93.00-96.00$ & $95.00 \pm 1.00^{\mathrm{a}}$ & \multirow{7}{*}{$\begin{array}{c}91.81 \pm 0.86 \\
83.00-98.00\end{array}$} & \multirow{7}{*}{$\begin{array}{l}4.010 * \\
(0.011)\end{array}$} \\
\hline & Boar $2(n=3)$ & $88.00-90.00$ & $89.00 \pm 0.58^{b}$ & & \\
\hline & Boar $3(n=3)$ & $93.00-98.00$ & $95.33 \pm 1.45^{\mathrm{a}}$ & & \\
\hline & Boar $4(n=3)$ & $95.00-97.50$ & $96.50 \pm 0.76^{\mathrm{a}}$ & & \\
\hline & Boar $5(n=4)$ & $87.00-95.00$ & $91.75 \pm 1.79^{\mathrm{ab}}$ & & \\
\hline & Boar $6(n=4)$ & $86.00-91.00$ & $88.75 \pm 1.11^{b}$ & & \\
\hline & Boar $7(n=4)$ & $83.00-95.00$ & $88.50 \pm 2.75^{b}$ & & \\
\hline \multirow{7}{*}{$\begin{array}{c}\text { Functional } \\
\text { membrane } \\
\text { integrity } \\
\text { (in per cent) }\end{array}$} & Boar $1(n=3)$ & $64.00-74.50$ & $69.50 \pm 3.04^{\mathrm{abc}}$ & \multirow{7}{*}{$\begin{array}{c}70.71 \pm 1.73 \\
55.50-87.00\end{array}$} & \multirow{7}{*}{$\begin{array}{l}3.864 * \\
(0.013)\end{array}$} \\
\hline & Boar $2(n=3)$ & $69.00-79.00$ & $74.33 \pm 2.91^{\mathrm{ab}}$ & & \\
\hline & Boar $3(n=3)$ & $65.00-72.00$ & $68.33 \pm 2.03^{b c}$ & & \\
\hline & Boar $4(n=3)$ & $55.50-63.00$ & $58.83 \pm 2.20^{c}$ & & \\
\hline & Boar $5(n=4)$ & $74.00-87.00$ & $80.25 \pm 2.78^{\mathrm{a}}$ & & \\
\hline & Boar $6(n=4)$ & $60.00-83.00$ & $66.75 \pm 5.45^{\mathrm{bc}}$ & & \\
\hline & Boar $7(n=4)$ & $68.00-80.00$ & $74.00 \pm 2.74^{\mathrm{ab}}$ & & \\
\hline
\end{tabular}

*: Means with different superscript in a column for a given parameter differ significantly $(p<0.05),{ }^{n s}$ : nonsignificant

According to Crabo (1997), sexually immature boars aged around 6-7 months tended to have a higher per cent of abnormalities than older boars. Acceptable boar semen ejaculate should not cross 20 per cent of total morphological aberrations for further processing (Johnson et 
al., 2000). Thus, the sperm abnormality values obtained in present study were within the normal permissible levels.

The overall per cent of (mean \pm SE) acrosome intact spermatozoa recorded in the present study of fresh semen ejaculates was $91.81 \pm$ 0.86 per cent with a range of 83.00 to 98.00 per cent. On an individual boar basis the intact acrosome per cent varied from $88.50 \pm 2.75$ to $96.50 \pm 0.76$ per cent. Significantly higher $(\mathrm{p}<0.05)$ acrosome integrity was observed in boar 1, 3 and 4 and no significant variation was found between them. Significantly lower $(p<0.05)$ values was observed in boar 2, 6 and 7 and no significant difference was noticed between these boars. The findings was found similar to the values reported by Kommisrud et al., (2002, 93.9 per cent) but the results observed in the current study were higher than those reported by Das et al., (2016) in Zovawk boar (71.8 \pm 0.29 per cent). Pursel (1979) reported that the damage to acrosome increased with duration of storage rather than the extender used because of per oxidation effect.

The overall per cent of (mean \pm SE) functional membrane integrity tested by HOST in the present study was found to range from 55.50 to 87.00 per cent with an average of $70.71 \pm$ 1.73 per cent. Individual boar sperm response to HOST per cent varied from $58.83 \pm 2.20$ to $80.25 \pm 2.78$. Significantly higher $(\mathrm{p}<0.05)$ HOST per cent was found in boar 5 and significantly lower $(\mathrm{p}<0.05)$ HOST per cent was found in boar 4 . The values observed in the present study were comparable with the results recorded by Das et al., (2016, $69.55 \pm$ 0.45 per cent) in Zovawk breeds of boar. However Kumaresan et al., (2009) recorded as low as $54.67 \pm 0.66$ per cent of HOS positive sperms in his studies. When spermatozoa were hypo-osmotically stressed, those with a biochemically active membrane will permit the influx of water through an intact membrane until it reaches osmotic equilibrium. This is suggestive of normal functional activity of the sperm membrane (Saravia et al., 2004). Matson et al., (2008) considered Hypo osmotic sperm swelling response as an indicator of fertility.

It could be concluded that LWY boar ejaculates, found suitable for liquid semen preservation, differed between boars with respect to gel free volume, sperm viability, abnormality, acrosome integrity and HOS response. While no such differences could be observed in the measurements of $\mathrm{pH}$, sperm concentration and progressive motility between ejaculates of different boars.

\section{References}

Campbell, R. G., Hancok, J. L. and Rothschild, L. 1953. Counting live and dead bull spermatozoa. J. Exp. Biol. 30: 44.

Cerolini, S., Maldjian, A., Pizzi, F., and Gliozzi, T.M. 2001.Changes in sperm quality and lipid composition during cryopreservation of boar semen. J. Reprod. Fertil. 121: 395401.

Crabo B. G. 1997. Reproductive examination and evaluation of the boar. In: Youngquist, RS ed. Current Therapy in Large Animal Theriogenology. W.B. Saunders Company, Philadelphia, pp. 664-670.

Das, A. K., Lalrintluanga, K., Ahmed, F. A., Ahmed, N., Ali, M. A., Subudhi, P. K., and Deuri, D. 2016. Holding time influences frozen semen quality of mizolocal boar (Zovawk). Indian J. Anim. Reprod. 37 (2): 59-60.

Frunza, I., Cernescu, H. and Korodi, G. 2008. Physical and chemical parameters of boar sperm. Lucrariştiintifice Med. Vet. 41: 634-640.

Hafez, E.S.E. 1993. Reproduction in Farm Animals. (6 ${ }^{\text {th }}$ Ed.). Lea and Febiger, Philadelphia, 573p.

Jeyendran, R. S., Van Der Ven, H. H., PerezPelaez, M., Crabo, B. G. and Zaneveld, L. J. D. 1984. Development of an assay to assess the functional integrity of the human sperm membrane and its 
relationship to other semen characteristics. J. Reprod. Fertil. 70: 219-228.

Johnson, L.A., Weitze, K.F., Fiser, P. and Maxwell, W.M.C. 2000.Storage of boar semen. Anim. Reprod. Sci. 62: 143-172.

Kantharaj, S. 2001. Evaluation of boar semen extended in Beltsville thaw solution. MVSc thesis, Kerala Agricultural University, Vellanikara, 84p.

Kommisrud, E., Paulenz, H., Sehested, E. and Grevle, I.S. 2002. Influence of boar and semen parameters on motility and acrosome integrity in liquid boar semen stored for five days. Acta Veterinaria Scandinavica, 43(1): p.49.

Kumaresan, A., Kadirvel, G., Bujarbaruah, K.M., Bardoloi, R.K., Das, A., Kumar, S. and Naskar, S. 2009. Preservation of boar semen at $18^{\circ} \mathrm{C}$ induces lipid peroxidation and apoptosis like changes in spermatozoa. Anim. Reprod. Sci. 110: 162-171.

Labussiere, J. 1990. Cited by Frunza et al., 2008.

Lalrintluanga, K., Deka, B.C., Nath., K.C., Hmar, L., Bhuyan, D., and Biswas, R.K. 2016. Effect of Different Extenders on the Quality of Boar Semen during Preservation At $18^{\circ}$ C. Int. J. Multidisciplinary Approach Studies. 3(1): 224-232.

Mann, T. 1974. Secretory function of the prostate, seminal vesicle and other male accessory organs of reproduction. J. Reprod. Fert. 37: 179-188.

Matson, P., Kappelle, W. and Malecki, I. 2008. The use of a hypo-osmotic swelling (HOS) test on sperm of the pig (Sus scrofa domesticus), emu (Dromaius novaehollandiae), Asian elephant (Elephas maximus), hamadryas baboon (Papio hamadryas hamadryas), and central rock rat (Zyzomys pedunculatus). Reprod. Bio. 9(2): 181-187

Murty, R. P. 1974. Physical characteristics of boar semen, preservation and artificial insemination in swine. MSc Thesis, Andhra Pradesh Agricultural University. $79 p$.

Pursel, V. G. 1979. Effect of cold shock on boar sperm treated with butylated hydroxytoluene. Biol. Reprod. 21(2): 319324.

Salisbury, G.W., Van Denmark, N.L. and Lodge, J.R. 1985. Physiology of Reproduction and Artificial Insemination of Cattle. $\left(2^{\text {nd }}\right.$ Ed.). C.B.S. Publishers and Distributors, Delhi, 798p.

Saravia, F., Wallgren, M., Nagy, S., Johansisson, A. and Rodriguez-Martinez, H. 2004. Deep freezing of concentrated boar semen for intra-uterine insemination. Theriogenology. 63(5): 1320-1333.

Sreekumaran, T.1974. Studies on boar semen. M.Sc thesis, University of Calicut. 75p.

Strzezek, J., Korda, W., Glogowski, J., Wysocki, P., Borkowski, K. 1995. Influence of semen-collection frequency on sperm quality in boars, with special reference to biochemical markers. Reprod. Dom. Anim. 30: 85-94.

Watson, P. F. 1975. Use of a Giemsa stain to detect changes in acrosome of frozen ram spermatozoa. Vet. Rec. 97: 12-15.

\section{How to cite this article:}

Shylesh, T., Hiron M. Harshan, Megha Wilson, K. Promod, A. P. Usha, C. Sunanda and Unnikrishnan, M. P. 2019. Fresh Semen Characteristics of Large white Yorkshire Boar Semen Selected for Liquid Semen Preservation. Int.J.Curr.Microbiol.App.Sci. 8(09): 1584-1590.

doi: https://doi.org/10.20546/ijcmas.2019.809.181 